\title{
Why Enhancement of Floral Resources in Agro-Ecosystems Benefit Honeybees and Beekeepers?
}

\author{
Decourtye Axel1, Alaux Cédric ${ }^{1}$, Odoux Jean-François², \\ Henry Mickaël ${ }^{1}$, Vaissière Bernard E. ${ }^{1}$ and Le Conte Yves ${ }^{1}$ \\ ${ }^{1}$ UMT PrADE, INRA - UMR Abeilles et environnement, \\ Site AgroParc, AVIGNON Cedex 9 \\ INRA, Unité expérimentale d'entomologie Le Magneraud, Surgères
}

France

\section{Introduction}

Honeybee (Apis mellifera L.) populations have experienced serious losses in Europe and North America (Neumann \& Carreck, 2010; Oldroyd, 2007). These losses highlights the potential risks for our natural and agricultural landscapes through lack of pollination, and the repercussions these would have for human activities and nutrition (Aizen \& Harder, 2009; Gallai et al., 2009; Klein et al., 2007; Rader et al., 2009; Ollerton et al., 2011). There is a great deal of concerns about the decline of honeybees across the world and what has been termed colony collapse disorder in the USA. Honeybee health is influenced by biotic factors such as availability of resources, competitors, pathogens, parasites, and predators, and abiotic factors such as climate and pollutants. Colony losses are likely due to multiple factors (Oldroyd, 2007), and most research to date has focused on epidemiological studies affecting honeybee health (Cox-Foster et al., 2007; Johnson et al., 2009; Le Conte et al., 2010), and on the negative effects of agricultural pesticides (Decourtye \& Devillers, 2010; Desneux et al., 2007; Johnson et al., 2010; Kevan, 1977). Although the putative causes of this decline are still being investigated, it has long been recognized that a lack of food, and particularly a dearth of pollen, within intensively farmed agricultural landscapes has contributed to the loss of colonies (Mattila \& Otis, 2006; Maurizio, 1950; Naug, 2009). Beekeepers have frequently cited starvation and poor foraging conditions as the principal causes of the recent bee losses (Allier et al., 2010; vanEngelsdorp et al., 2007). Naug (2009) suggested that nutritional stress due to habitat loss has played an important role in honeybee colony collapse, and thereby stressed the usefulness of protecting and enhancing the availability of flower resources by using rules and policies for efficient management of agricultural farmlands. Decourtye et al. (2010) reviewed potential approaches to provide and maintain diverse floral resources in a landscape, giving particular consideration to herbaceous plants, to sustain bee populations, and support honeybee health and beekeeping. These approaches include the cultivation and maintenance of large strips (6-12 $\mathrm{m}$ in width) of native or non native melliferous plants maintained between crop fields, fallow areas, field margins, and conservation buffer strips. To set up an favourable landscape for honeybees, 
it is essential to understand the relationship between this insect and the melliferous or polleniferous flora in their environment. This is the main goal of this review and we also describe some available data on the effects of diet on some biological functions of bees so as to build a scientific background for agro-environmental measures protecting floral resources and benefiting the beekeeping industry.

\section{A brief presentation of the honeybee}

\subsection{A social insect}

The honeybee is a eusocial insect, living in colonies that can be made of up to 50,000 individuals, including a fertile female, the queen, workers which are sterile females, males (drones), and brood (eggs, larvae and pupae). The workers do various tasks in succession during their lifetime depending on their age and the environment, such as maintaining and building combs, feeding larvae, feeding and grooming the queen and other members of the colony, ventilation, reception and storing of collected food, and defending the nest. From about 21-day old on to their death, the main part of their activity is outside the hive, gathering pollen, nectar, water and propolis. By visiting flowers, forager bees provide the colony with nectar and pollen, which are subsequently transformed into honey and "bee bread", respectively. Survival of the colony depends on the reserves made from these supplies in the combs, especially during the winter.

\subsection{Nectar and pollen gathering}

Nectar and pollen gathering often occur together as the flowers of most plant species are hermaphrodites and provide both resources. But foraging bee can also collect only one resource and be strict nectar or pollen collector. Indeed, some plants produce on one hand little or no nectar, but offer an abundance of pollen (e.g. kiwifruit Actinidia deliciosa A. Chev.; Vaissière et al., 1996), while others produce large echinate pollen grains that honeybees cannot pack on their hind legs (e.g. cotton Gossypium hirsutum L; Vaissière \& Vinson, 1994). In addition it was demonstrated that a tendency to prefer pollen foraging is genetically determined (Page et al., 1995). Despite this, for reasons of adaptability to the environment and to the colony needs, honeybee worker can rapidly change their foraging activities based on mechanisms of communication and learning.

\subsection{Foraging efficiency depends on communication and learning}

At the colony level, honeybees are communicating through dances to exchange information about the location of food sources which have been located by scout workers (von Frisch, 1967). Also, the foraging activities vary according to the colony needs communicated by trophallaxis (exchange of food and secretions from mouth to mouth) and exchanges of pheromones inside the colony (Winston, 1987). At the individual level, the foraging worker can remember the configuration of the foraging area and the characteristics of the food sources (Menzel et al., 1993). This last point raises the question of the appreciation of flower attractiveness by the bees. Bees are first attracted by floral odours which can be perceived from far away (Loper \& Waller, 1970). But overall it is the association between the reward (quantity and quality of pollen or nectar supplied) and the characteristics of the flower such as odour, colour, and shape, that enables the learning and subsequent recognition of a flower. A flower type providing little resources 
will be quickly abandoned to the expense of a more profitable type of flower, if the food supply in the environment allows it (Winston, 1987).

Under experimental conditions, honeybees prefer nectar containing saccharose (Waller, 1972) and are able to assess differences in sugar concentrations in the order of $5 \%$ (Jamieson \& Austin, 1956). They prefer concentrated nectars that range in sugar content between $15 \%$ to 50\% (Jamieson \& Austin, 1956; Sigurdson, 1981a, 1981b; Waddington \& Kirchner, 1992; Waller, 1972), but they avoid nectars which are too viscous and thus make their collection difficult. Nectar accessibility also influences floral choice by nectar foragers as nectar has to be within reach given their proboscis length. Honeybees have an average tongue length of $6 \mathrm{~mm}$ and can often gather little nectar from flowers with deep corolla such as those of red clover (Trifolium pratense L.) and several other Fabaceae (Jablonski, 2001).

For pollen, the protein content does not seem to be detected by the foragers (Maurizio, 1954). Pollens which have the highest protein content are not necessarily those which are the most sought after or the most appetizing. Thus, the fact that a pollen is collected by honeybee foragers does not provide information about its nutritive value. Indeed, pollen from female kiwifruit vines is readily collected by honeybees while its nutritive value is very low (Jay \& Jay, 1993). It is not easy to establish a link between the protein content and the nutritive value of a given pollen, because pollen grains contain many other elements besides proteins, and also because their proteins are more or less digestible. Digestibility essentially depends on the thickness and ornementation of the pollen wall. Moreover, a lack of rich pollen in the environment can result result in workers collecting pollen completely deficient of any nutritive value (Louveaux, 1959; Maurizio, 1954; Wille et al., 1985). Also accessibility is an important factor for pollen collection since honeybees cannot harvest large pollen grains which are echinate with long spines such as those of cotton and several other Malvaceae (Vaissière \& Vinson, 1994). And the overall appetence of pollen is also influenced by the presence or absence of phago-stimulants or repulsive compounds (Pernal \& Currie, 2000).

\subsection{Flower loyalty and foraging areas}

Honeybees respond to groups of stimuli and rewards that are characteristic of each floral type. Both pollen and nectar gathering by a forager are made more efficient by the fact that the bee learns the handling of a floral type that it finds profitable and then remains loyal to this type for as long as it is available. Indeed, one can observe specialized foraging positions on most flower types (Robinson, 1989) and a strong area loyalty. Indeed, the individual foraging area of honeybee foragers is limited to an area of ca. $100 \mathrm{~m}^{2}$ (Singh, 1950).

Yet one must not confuse the foraging area of an individual forager with that of the colony as a whole. Within the colony, different foraging groups target different sites. In an environment where nectar is abundant, the foraging area of a colony is on average ca. 2 $\mathrm{km}$ radius around the hive. And $90 \%$ of bees dancing gather pollen in a radius of less than $5 \mathrm{~km}$ from the hive (Beekman \& Ratnieks, 2000; Steffan-Dewenter \& Kuhn, 2003), that is a survey area of about $80 \mathrm{~km}^{2}$. When needed, a colony can expand considerably its foraging area. Beekman \& Ratnieks (2000) noted that 50\% of the foraging bees foraged at $>6 \mathrm{~km}$, and $10 \%$ at $>9 \mathrm{~km}$. Based on these results, the flowering areas targeted at the honeybees could be safely created and protected within a $1 \mathrm{~km}$ radius around the hive. But in intensively farmed landscapes that are flower-poor, the foraging activity can take place 
readily over several kilometres around the hive (Decourtye et al., 2008; Steffan-Dewenter \& Kuhn, 2003).

\section{Characteristics and composition of food sources}

\subsection{Nectar}

Nectar is the dominant source of carbohydrates and is therefore an energy source immediately available to fill colony needs. However, while the hive workers frequently visit honey cells, the food gathering foragers do not as they are fed by nurse honeybees through trophallaxis (Crailsheim et al., 1996). Thus nectar reserves, progressively transformed into honey by the workers, fuel the global activities of the colony, including food collection itself. Honey reserves also enable over-wintering survival of adults, as no extra food is gathered at this period.

Nectar is generally produced in the floral nectary, but some plants also have extra-floral nectaries (Elias, 1983). Studies of more than 900 plant species revealed that both floral and extra-floral nectaries contain 3 main sugars: glucose, fructose and saccharose, in proportions characteristic of the plant species (Baker \& Baker, 1982). In addition, small quantities of proteins, lipids and amino acids are also found in nectar (Baker \& Baker, 1982), as well as other substances that may help its spotting by bees (Thorp et al., 1975).

While the sugar composition of nectar is relatively stable, the volume and concentration of the nectar are quite variable. In entomophilous plants (pollinated by insects) growing in temperate regions, the volumes are most frequently in the order of 0.5 to $7 \mu \mathrm{L} /$ flower, with a modal value of $2 \mu \mathrm{L}$ (Cruden et al., 1983), while sugar concentrations vary from $5 \%$ to $50 \%$ depending on the species (Baker \& Baker, 1982; Cruden et al., 1983). Nectar secretion is subject to a specific rhythm, and, for each species, not only is there a large difference between secretion rate between day and night, but also nectar production can vary considerably during the course of a day (Maurizio, 1975). According to Maurizio (1975) and Corbet et al. (1979), optimal nectar secretion, in volume and sugar concentration, is produced during a period of 5 hours on average, either in the morning, or at the end of the afternoon in the majority of plants that are pollinated by hymenopteran pollinators. More rarely, certain plants show two secretion peaks : one in the morning and one in the evening. It is also noteworthy that even within a given plant species, large differences can exist in the secretion pattern between populations and varieties (e.g., oilseed rape Brassica napus L.; Pierre et al., 1999).

Apart from genetic factors, nectar production (volume and concentration) depends on the developmental stage of the plant, as well as the time of day and the age and position of the flower on the plant. Even more, it depends largely on environmental factors such as soil type and moisture level, cultivation practices, and weather conditions (wind, temperature, relative humidity).

From this brief review, it appears that honeybees are clearly in a situation where nectar supply can not only be very diverse in that it is usually provided by an array of several plant species, but also extremely variable in amount and composition. The colony can thus go from a situation when nectar supplies are totally absent, to a situation where there is an abundance of nectar over just a few days (Crane, 1975). Honeybees have therefore to adapt rapidly their foraging depending upon the nectar and pollen availability in their environment. 


\subsection{Pollen}

Pollen is produced and released by the anthers and it can be more or less accessible to the floral visitors depending on floral morphology. Honeybees rarely eat it in its natural state. Rather, it is first aggregated with nectar or diluted honey to form pellets (Vaissière \& Vinson, 1994). Pellets are then placed in the cells, packed and covered with honey and it is transformed by lactic fermentation to make « bee bread ».

Fresh pollen contains proteins and amino acids, but also carbohydrates and lipids, including sterols. Each type of pollen can be characterised by its global caloric value, its protein content as \% of dry matter, its nitrogen content, amino acid composition (classified as essential or non essential), and starch, sugar and lipid content as well as its vitamin and mineral elements. Specific techniques are needed for each of these measurements and results often differ between different authors. It is therefore difficult to obtain the complete biochemical profile for the pollen of a given plant species (Stanley \& Linskens, 1974). For example, dandelion pollen (Taraxacum campylodes G.E. Haglund), has a protein content that ranges from 9.2 to $19.2 \%$ of its dry weight, depending on the authors, its main lipids are made up linoleic and palmitic acid, and its mineral element composition is known as well. We also know that it is deficient in arginine and is missing essential amino acids such as tryptophane and phenol-alanine (Loper \& Cohen, 1987). A few other complete data exists on pollen of gymnosperms and corn Zea mays L., but generally such complete data sets are rare and does not allow a multi-criteria classification of pollen types.

\subsection{Nectar and pollen budget of the colony}

Large quantities of food are required by a honeybee colony. Food gathering at the height of the season must be enough to feed 50,000 workers and 9,000 larvae. Such colony may have an annual nectar budget of about $120 \mathrm{~kg}$ and a pollen budget of $20 \mathrm{~kg}$ (Seeley, 1995). It may stock from 60 to $80 \mathrm{~kg}$ of honey per year (Erber, 1992; Rosov, 1944; Seeley, 1995; Weipple, 1928. The larva of a worker honey bee consumes about $140 \mathrm{mg}$ of honey during its development (Rosov, 1944; Seeley, 1985; Weipple, 1928; Winston, 1987).

An active foraging worker uses $0.5 \mathrm{mg}$ of honey per $\mathrm{km}$ flown, and it can fly as much as 800 $\mathrm{km}$ during its lifetime (Gould \& Gould, 1988). Others authors estimated that a forager consumed $11.5 \mathrm{mg}$ of sugars per hour in flight, and only $0.7 \mathrm{mg}$ per hour when inside the hive (Heinrich, 1979; Olaerts, 1956). During winter, bee activity is reduced, but the cluster must maintain a constant temperature in the centre of the nest of $34^{\circ} \mathrm{C}$ to $36^{\circ} \mathrm{C}$, which requires a large energy expenditure. Thus, an average sized colony needs to stock ca. $25 \mathrm{~kg}$ of honey for winter consumption. Overall, the annual needs of a colony are estimated at about $80 \mathrm{~kg}$ of honey and $20 \mathrm{~kg}$ to $40 \mathrm{~kg}$ of pollen depending upon the authors (Crailsheim et al., 1992; Louveaux, 1954; Winston, 1987).

A colony gathers from 15 to $55 \mathrm{~kg}$ of pollen per year (Eckert, 1942; Hirschfelder, 1951; Louveaux, 1958; Ribbands, 1953; Seeley, 1985). Nursing bees are the ones that consume the most pollen as they eat ca. $60 \mathrm{mg}$ of pollen over 10 days (Pain \& Maugenet, 1966), to develop their hypopharyngeal glands which produce the $42 \mathrm{mg}$ of food consumed by larvae during the first 5 days of larval development (Haydak, 1968). This food given by nursing bees constitutes a major part of the protein supply consumed by larvae since pollen is processed into brood food and only $5 \%$ of the protein derived from pollen are directly fed to larvae (Babendreier et al., 2004). 
Clearly, the survival and development of honeybee colonies are influenced by the regularity, quality and quantity of the nectar and pollen supply. Within intensively farmed agricultural landscapes, nectar- and pollen-producing crops may provide a narrow window with mass flowering followed by a dearth of pollen and nectar resources. A typical example occurs with oilseed crops such as rape and sunflower (Helianthus annuus L.) for which nectar and pollen resources are usually abundant during the blooming, but only for a short period. The subsequent temporal dearth of resources could be partially filled simply by the creation and protection of additional non-cropped areas such as field margins (strips bordering crop fields), hedgerows (linear scrub along field boundaries), woodlands, ponds, ditches and fallow farm fields (Decourtye et al., 2010).

But, for both pollen or nectar, it is long and difficult to assess precisely their production in quantity and quality. Indeed, one must not only take into account the effects from the environment but also the effects of the genetic make-up of the plants at the species and variety levels. This last point is important to objectively assess the best flowering plant for bees, though it is rarely known.

\section{Impact of pollen supply on the life of the colony}

The majority of the protein intake of larvae comes from the hypopharyngeal gland secretions of nurse bees, and the development of these glands depends on their pollen diet. The development of hypopharyngeal glands is not dependant upon the essential amino acids present in the pollen consumed, but on the total quantity of protein ingested (Pernal \& Currie, 2000). Therefore, a situation of pollen deficiency may have detrimental effects on the nurse bees' tasks and brood care, resulting in undernourished larvae (Blaschon et al., 1999). When such deficiencies occur, the nurse bees may also reduce the number of larvae to feed and cannibilize the eggs (Schmickl \& Crailsheim, 2001). The young larvae are eliminated for the benefit of the older larvae which need more pollen input. In the case of extended pollen deficiency, another strategy is to reduce overall larval care (Blaschon \& Crailsheim, 2001). Finally, pollen feeding during the larval stage has an important impact on the traits of the adults as it may determine the size of the future adult (Roulson \& Cane, 2000) and its life expectancy (Schmidt et al., 1987).

Ovary development is another major process influenced by pollen intake. Experiments have been carried out on worker bees kept in isolation without queen, in order to evaluate their capacity to develop ovaries, a physiological process highly dependent protein utilization and pollen quality. This method has shown that pollen from apple (Malus domestica Borkh.) or sweet clover (Melilotus spp.) is favourable to ovary development whereas pollen from pine (Pinus spp.) is not and that of sunflower is below average (Pernal \& Currie, 2000). Also, a diet consisting of several pollens of different nutritive value is not equivalent to their average nutritive value ( Taséi \& Aupinel, 2008; Alaux et al., 2011). We can also assume that a pollen of low nutritional value, like that of dandelion, can be compensated by mixing it with another pollen that has a higher nutritional value for reproductive needs (Genissel et al., 2002). This highlights the importance of avoiding putting bees in a situation where they do not have sufficient floral variety, as is often the case amidst large intensive agricultural landscapes.

Finally, it has recently been shown that a high concentration of pollen lipids (mainly linoleic, myristic and dodecanoic acids) protects the brood nest from certain bacteria such as Paenibacillus larvae and Melissococcus pluton which are the pathogenic agents responsible for 
American foul-brood and European foul-brood, respectively (Manning, 2001). Likewise, a diet with reduced pollen quantity and diversity can induce not only a protein deficiency, but also a decreased synthesis of detoxification enzymes. As a result, bees fed with a mixed pollen diet can be less sensitive to some pesticides (Wahl \& Ulm, 1983).

\section{What are the benefits of diet diversity?}

Within complex landscapes, honeybee colonies normally collect and consume pollen from a large array of plant species (Dimou \& Thrasyvoulou, 2009; Louveaux, 1959; Severson \& Parry, 1981). This generalist behavior for pollen collection (polylecty), as opposed to oligolecty or monolecty in other bee species, is further supported by experimental evidence that honeybees feed preferentially on plurispecific pollen mixtures rather than pollen from a single species (Schmidt, 1984). These results support the postulate that honeybees select a mixed diet when given a choice. However, today intensive agricultural landscapes most often provide colonies with a low variety of plant species. Indeed, honeybees used for the pollination service of large areas may even be forced to feed mainly on a single flowering crop, like sunflower that has pollen with a poor nutritional value and sesame that has pollen which contains only low levels of phagostimulants (Schmidt et al., 1995). Such practices may be stressful for colony health. In those cases, the presence of additional floral or food sources could to reduce these potential problems.

The protein content of pollen ( 2.5 to $61 \%$ ), its amino acid composition, its lipid content ( 1 to $20 \%)$, and that of starch, sterols, vitamins and minerals vary tremendously among plant species (Roulston \& Buchmann, 2000; Roulston \& Cane, 2000; Stanley \& Linskens, 1974). Therefore, regardless how much monospecific pollen is consumed, it might miss nutrients essential to the health of honeybee colonies. The deficiency of a given pollen in essential nutrients could be compensated for by a more diverse pollen diet. Indeed, a mixed pollen diet increases the lifespan of honeybees as compared to a monospecific pollen diet (Schmidt, 1984; Schmidt et al., 1987). In addition, a diversified pollen diet might help the bees to fight against pathogens. Alaux et al. (2010) found that a diverse pollen diet can actually enhance some immune functions in worker honeybees. For example, their production of glucose oxidase, an enzyme involved in the synthesis of the antiseptic hydrogenperoxide in honey and brood food, was $40 \%$ higher in honeybees fed with pollen from a variety of plants compared to those fed with pollen from a single plant species - even if this monofloral diet had a higher protein content. However, whether polyfloral diets might increase the actual resistance to diseases and pathogens remain to be tested. In bumblebees Bombus terrestris, larvae fed with a mixed pollen diet were heavier than larvae fed with monofloral pollen of equivalent or higher protein content (Taséi \& Aupinel, 2008), and so we might also expect a similar beneficial effect of a diverse pollen diet on the health of honeybee larvae.

As stated previously, increasing the number of pollen species in the diet probably provides a buffer against deficiencies of specific nutrients (Schmidt, 1984) as well as the presence of toxic compounds in some pollen (Mesquita et al., 2010). Indeed, several studies have demonstrated the importance of some specific nutrients in bee health. For example, de Groot (1953) found that 10 essential amino acids in specific proportions are required for optimal honeybee health: arginine, histidine, lysine, tryptophan, phenylalanine, methionine, threonine, leucine, isoleucine, and valine. Those essential amino acids cannot be synthesized de novo by honeybees and therefore need to be supplied directly in the diet. Some fatty acids, found at different levels in pollens ( Manning, 2001; Singh et al., 1999), can also be beneficial 
to honeybees due to their antimicrobial properties (Hornitzky, 2003). Pollen and nectar, beside being the primary food source for bees, also contain phytochemicals and are often rich in carotenoids, flavonoids, alkaloids and phenolic compounds that have antioxidant properties and antimicrobial activity (Adler, 2000; Balch \& Balch, 1990; Basim et al., 2006; Campos et al., 2003; Leblanc et al., 2009; Morais et al., 2011). Sustaining the diversity of flower resources in the landscape might increase the chances for bees to find all those beneficial nutrients, and also to avoid or provide an alternative to toxic nectar and pollen. Indeed, some plant components are non-nutritive but toxic to honey bees (Barker, 1990), like the sugars galactose, arabinose, xylose, melibiose, raffinose, stachyose and lactose that can be found in pollen and nectars of some plants (Barker, 1977).

\section{Availability of food resources in the environment: a question of temporal and spatial scales}

Currently, there is no temporal continuity in floral resource availability within intensively farmed agricultural landscapes. In Europe, mass flowering crops providing bees with nectar or pollen are often limited to maize, sunflower and oilseed rape at large landscape scales in cereal farmland systems (Decourtye et al., 2010). Among these three, maize provides the greatest quantities of pollen collected by honeybees, due to its long-lasting availability and good accessibility to foragers (Charrière et al., 2010; Odoux et al., 2004; Vaissière \& Vinson 1994). On the other hand, oilseed rape and sunflower can be important nectar sources and provide substantial honey crops. This abundance of resource often has a strong impact on colony dynamics as the high intake of food during the flowering of the oilseed rape induces a rapid demographic increase in the colonies. Unfortunately, these young and populous bee cohorts are likely to suffer from food resource scarcity after the mass flowering ends.

Beekeeping takes place in a great variety of agrosystems and is therefore exposed to a wide range of colony management issues. The foraging ecology of honeybees has to be considered within temporal and spatial scales as well. Cereal plains often include also seminatural habitats, which are able to supply food resources for honeybees during periods of food shortage. Therefore, bees shift foraging habitats on a seasonal basis. The capacity of these agricultural environments to sustain honeybee colonies between crop mass-flowering periods depends on the presence of wild plants in hedgerows, grasslands and woody habitats. In other words, the carrying capacity of the landscapes is expected to increase with its structural complexity (Steffan-Dewenter \& Kuhn, 2003). During periods of food shortage, bees can cover larger distances to fetch food, e.g. beyond $5 \mathrm{~km}$ away from the colony (Beekman \& Ratnieks, 2000; Odoux et al., 2009). In addition, some weeds in cereal fields probably become keystone resources at this time. For instance, bees may collect on a daily basis more pollen on poppy flowers (Papaver rhoeas L.), than they would on maize (Odoux, 2010). The presence of this adventicious species is clearly dependant on agricultural practices such as crop rotation, soil preparation, and herbicide use.

The nutritional carrying capacity of farming landscapes for honeybees varies a lot, as food resources vary in quantity and quality. The cultivated lavender hybrid (Lavandula $x$ intermedia Emeric ex Loisel) is an attractive melliferous crop for beekeeping, but it is malesterile so that it does not provide any pollen at all. On the contrary, apple orchards produce an abundant pollen that is rich in proteins (Louveaux, 1959). Abundant intakes of sunflower and maize pollens, which are particularly poor in protein and lipid content (Feuillet et al., 2008; Roulston \& Cane, 2000), are expected to exert stresses on colony 
demography. The pollen of some other grasses usually grown for fodder (e.g. Setaria italica L.P.Beauv.) are also actively foraged by honeybees during periods of pollen dearth, but this pollen does not appear satisfactory based on its nutrient content. In this regard, wild plant species such as wild cherries (Prunus avium L.) or wild poppies offer proteinand lipid-rich pollens, and enable a stable development of colonies in the spring, when the blooming of the oilseed rape is over.

In intensive agricultural landscapes where semi-natural habitats and weeds are sparse, floral schemes, i.e. management of flowering areas, might provide ecological compensation features for honeybees (Decourtye et al., 2010). They are intended foremost to ensure population sustainability during the periods of food shortage rather than to foster honey production. Such floral schemes might also contribute to the conservation of some wild bee species. Indeed Fabaceae, which are also visited extensively by wild bees, are often preferred in the agri-environmental schemes of farmers, since their management is wellknown and their seeds are generally fairly cheap. The efficiency of floral schemes to provide pollen resources to colonies can be assessed by analyzing the pollen pellets obtained for example with pollen traps. And the benefits for beekeepers are clear as colonies that have had access to more regular resources during a given season produced more brood and larger populations in the following year (Decourtye et al., 2008).

\section{Consideration of the landscape factors in agro-environmental actions promoting flowering areas}

Some authors have questioned the effectiveness of agro-environmental schemes because their beneficial effects on target species do vary from one study to another (Kleijn et al., 2006). The same holds true for floral landscape enhancements dedicated specifically to bees (Dicks et al., 2010). Yet there is a growing body of evidence that the seemingly unpredictable effectiveness of floral schemes is actually dependent on the landscape context in which it is established (Decourtye et al., 2010). Landscape context typically refers to the degree of land use by humans. Intensive, simplified, agricultural landscapes are distinguished from complex landscapes with greater amounts of semi-natural habitats or habitat diversity. A handful of studies have specifically measured the influence of landscape context on the efficiency of experimental flower patches in attracting bees (Heard et al., 2007; Kohler et al. 2008; Steffan-Dewenter et al., 2002). However, to date, no consistent conclusion can be drawn on such floral schemes because different field protocols have been used with different study species and at different spatial scales.

Only one of these studies (Steffan-Dewenter et al., 2002) focused on honeybees and it reported a weak pattern of context-dependent floral scheme effectiveness. Authors have implanted experimental flower patches in a variety of landscape contexts, and have monitored honeybee foraging activity at those patches. Flower patches tended to attract fewer honeybees when implanted in landscapes characterized by a higher amount of seminatural habitats (field and forest margins, hedgerows, fallows and extensive grasslands) within a $3-\mathrm{km}$ radius. Conversely, foraging activity at flower patches located in more intensive agricultural landscapes was greater, indicating that honeybees compensated for the lack of natural resources by making a disproportionate use of the floral schemes.

Yet, theoretical evidence suggests that honeybees would rather respond positively to the presence of semi-natural habitats. In particular, hedgerows, forest margins and other linear landscape elements may be used as visual landmarks by honeybees to direct their flight 
path and locate food sources (Chittka \& Geiger, 1995; Dyer, 1996; Dyer et al., 2008). As such, linear landscape elements are generally considered to promote landscape connectivity (Taylor et al., 1993), i.e. to facilitate movement of organisms among their resource patches by forming flight corridors (Townsend \& Levey, 2005; Van Geert et al., 2010).

The mismatch between theoretical expectations of higher foraging activity in complex landscapes on one hand, and the opposite pattern actually observed by Steffan-Dewenter et al. (2002) on the other hand, most probably reveal an interplay of behavioral processes acting at different spatial scales. The study by Steffan-Dewenter et al. (2002) reports broadscale patterns, with landscape context characterized within $250-\mathrm{m}$ to $3-\mathrm{km}$ radii around experimental plots, i.e. a spatial window scaled on the foraging range of honeybee colonies. However, the facilitative effect of visual landmarks for the orientation of foragers probably acts at a very local scale. Perception and orientation in honeybees imply short-scale behavioral processes. For instance, an experimental modification of landmark arrangements within a range of only several tens of meters altered the capacity of honeybees to retrieve food sources (Chittka \& Geiger, 1995).

Recent foraging surveys conducted in an intensive cereal farming system support the previous hypothesis that semi-natural and/or linear landscape elements enhance the use of floral schemes by honeybees at a local scale (Henry et al., in press). Honeybee foraging activity was monitored in 170 plots $(2 \times 2 \mathrm{~m})$ of Phacelia tanacetifolia Benth. scattered among 17 field margins, all positioned within the foraging range of a single experimental apiary. The presence of hedgerows and forest edges within a 160-m radius around the phacelia plots had a strong positive effect on honeybee foraging activity. Conversely, the presence of mass flowering crops within the same distance had a negative effect, probably because they exerted a concurrent attraction. This critical range of $160 \mathrm{~m}$ was not covered by the study of Steffan-Dewenter et al. (2002).

Altogether, the above-mentioned studies suggest that the effectiveness of floral enhancement schemes varies with landscape context in a multi-scale fashion. On a broad scale, i.e. at the landscape level envisioned by the foraging range of a honeybee colony (3$\mathrm{km}$ grain), floral schemes will be more successful in intensive agricultural landscapes (with $<15 \%$ of land cover occupied by semi-natural habitat remnants). At a smaller scale, within intensive landscapes, floral schemes will be more successful if they are implanted nearby $(<$ $160 \mathrm{~m}$ ) existing networks of hedgerows, forest edges, or other salient semi-natural elements. Priority should be given to areas farther $(>160 \mathrm{~m})$ from other existing mass-flowering crops. These tentative recommendations still need further validation, depending on the type of floral schemes.

\section{Conclusions}

Even if much research remains to be done to improve the assessment of the nutritive value of specific nectar, pollen and their mixes, it is clear that these resources are complementary and essential throughout the lifetime of honeybees. We have seen that, by a feedback loop system, a deficiency in quantity and quality of pollen and nectar can lead to a demographic decrease of the colony. A reduced pollen intake leads to low production of larvae and of course adults, and in turn less pollen and nectar foragers. The role of nectar and pollen is empirically so obvious that beekeepers now provide supplements in the form of syrup or pollen in case of deficiency. However, it must be highlighted that the suitability of pollen feeding depends on the storage method and duration of the pollen. The same holds true for 
the feeding of sugar syrup solutions. These cannot fully replace natural nectar in terms of nutritive value. Consequently, making sure that honeybees have access to pollen and nectar at the right time in their natural environment, remains the best way to guarantee colony survival. Moreover, recent results reported in literature (Alaux et al., 2010; DeGrandiHoffman et al., 2010) highlight a connection between diet, protein levels and immune response and suggest that colony losses might be reduced by alleviating diet stress through landscape enhancement of floral resources in agro-ecosystems.

The goal of agro-environmental measures aiming to favour honeybee protection should be to temporally and spatially increase heterogeneous habitats for these insects (Decourtye et al., 2010). As a first goal, it is urgent to preserve current semi-natural habitats in farmlands (hedgerows, woodlands, ponds, ditches). In addition, regulations advocating the management of uncropped farmlands (field margins, farmland set-aside) for increased floral availability to bees could contribute to the maintenance of colony viability (at risk today, especially in intensive cereal farming areas). The management of uncropped farmlands designed to introduce floral resources is likely to benefit other pollinators (wild species) and sustain beekeeping activities (domestic species). But the economic question has to be addressed in relation with farmers as well, depending on the possibility to derive any agronomic benefit from floral schemes. Land managers have to seek a trade-off between the costs of introducing floral schemes, and the benefits they might receive from it because of enhanced pollination service. Yet, enhancement of farmland set-aside may require disproportionate financial investments in some areas - generally where farming practices are intensive (Kleijn et al., 2009; Van Buskirk \& Willi, 2004). Therefore, it appears critical to gain a prior knowledge about where enhancement schemes are likely to reach maximal efficiency in a given landscape. In that respect, we should study the efficiency of flower enhancement schemes according to local landscape context. This issue has been poorly explored to date (Heard et al., 2007). Reliable modeling tools are needed to delineate the landscape areas likely to be associated with greater effectiveness of floral enhancement schemes, specifically in intensive agricultural systems.

In these intensive farming areas, the conflict between the conservation of flora, to increase the availability of food to bees, and the management of pesticide treatments complicates the reliability of the positive impact of such flowering schemes. The protection of plants producing nectar and pollen in the farmland areas must actually come with a harmless management of pesticides. Thus, rather than any particular farming practice causing current population decline, such as insecticide application or reduction of flora, the multivariate effects of agricultural practices strongly interact and should be considered collectively, rather than individually.

\section{Acknowledgements}

This work is a product of UMT PrADE, a unit which associates different groups of stakeholders towards bee protection, from researchers to apicultural engineers. It was financially supported in part by a grant from the French Ministry of Agriculture (MIRES). The research on the melliferous and polleniferous flora and pollen nutrients was supported by grants from FEAGA, L'Institut National de la Recherche Agronomique (INRA "Département Santé des Plantes et Environnement"), and a French-Romanian bilateral program (PHC Brancusi). 


\section{References}

Adler, L.S. (2000). The ecological significance of toxic nectar. Oikos Vol.91, pp. 409-420.

Aizen, M.A. \& Harder, L.D. (2009). The global stock of domesticated honey bees is growing slower than agricultural demand for pollination. Current Biology Vol.19, pp. 915918.

Alaux, C.; Ducloz, F.; Crauser, D. \& Le Conte, Y. (2010). Diet effects on honeybee immunocompetence. Biology Letter Vol.6, pp. 562-565.

Allier, F.; Holzmann, C.; Britten, V.; Jourdan, P. \& Vallon, J. (2010). Estimation of honeybee colony losses within professionnal beekeepers in France during winter 2008/2009, Proceeding of Eurbee, Ankara, Turkey, 2010.

Badendreier, D.; Kalberer; N.; Romeis; J.; Fluri, P. \& Bigler, F. (2004). Pollen consumption in honey bee larvae: a step forward in the risk assessment of transgenic plants. Apidologie, Vol.35, pp. 293-300.

Baker, H.G. \& Baker, I. (1982). Floral nectar constituents in relation to pollinator type. In: Handbooks of experimental pollination biology, C.E. Jones \& R.J. Little (Eds.), 131-191, van Nostrand-Reinhold, New-York.

Barker, R.J. (1977). Some carbohydrates found in pollen and pollen substitutes are toxic to honey bees. Journal of Nutition, Vol.107, pp. 1859-1862.

Barker, R.J. (1990). Poisoning by plants, In: Honey bee pests, predators, and diseases, R.A. Morse \& R. Nowogrodzki (Eds.), 306-328, Cornell University Press, New York and London.

Basim, E.; Basim, H. \& Ozcan, M. (2006). Antibacterial activities of Turkish pollen and propolis extracts against plant bacterial pathogens. Journal of Food Engineering, Vol.77, pp. 992-996.

Beekman, M. \& Ratnieks, F.L.W. (2000). Long-range foraging by the honey-bee, Apis mellifera L. Functional Ecology, Vol.14, PP. 490-496.

Blaschon, B.; Guttenberger, H.; Hrassnig, N. \& Crailsheim, K. (1999). Impact of bad weather on the development of the brood nest and pollen stores in a honeybee colony (Hymenoptera: Apidae). Entomology Genetic, Vol.24, pp. 49-60.

Campos, M.G.; Webby, R.F.; Markham, K.R.; Mitchell, K.A. \& Da Cunha, A.P. (2003). Aged induced diminution of free radicals scavenging capacity in bee-pollens and the contribution of constituents flavonoids. Journal of Agricultural and Food Chemistry, Vol.51, pp. 742-745.

Charrière, J.D.; Imdorf, A.; Koenig, C.; Gallmann, S. \& Kuhn, R. (2010). Do sunflowers influence the development of honey bee, Apis mellifera, colonies in areas with diversified crop farming? Journal of Apicultural Research, Vol.49, pp.227-235.

Chittka, L. \& Geiger, K. (1995). Can honey bees count landmarks? Animal Behaviour, Vol.49, pp. 159-164.

Corbet, S.A.; Unwin, D.M. \& Prys-jones, O.E. (1979). Humidity, nectar and insect visits to flowers, with special reference to Crataegus, Tilia and Echium. Ecological Entomology, Vol.4, pp. 9-22.

Cox-Foster, D.L.; Conlan, S.; Holmes, E.C.; Palacios, G.; Evans, J.D.; Moran, N.A.; Quan, P.L.; Briese, T.; Hornig, M.; Geiser, D.M.; Martinson, V.; vanEngelsdorp, D.; Kalkstein, A.L.; Drysdale, A.; Hui, J.; Zhai, J.; Cui, L.; Hutchison, S.K.; Simons, J.F.; Egholm, M.; Pettis, J.S. \& Lipkin, W.I. (2007). A metagenomic survey of microbes in honey bee colony collapse disorde. Science, Vol.318, pp. 283-287. 
Crailsheim, K.; Schneider, L.H.W.; Hrassnigg, N.; Bühlmann, G.; Brosch, U.; Gmeinbauer, R. \& Schôffmann, B. (1992). Pollen consumption and utilization in worker honeybees. Journal of Insect Physiology, Vol.38, pp. 409-419.

Crailsheim, K.; Hrassnigg, N. \& Stabentheiner, A. (1996). Diurnal behavioural differences in forage and nurse honey bees (Apis mellifera carnica). Apidologie, Vol.27, pp. 235-244.

Crane, E. (1975). The flower honey comes from. In: Honey, a comprehensive survey, E. Crane (Ed), 3-105, Heinemann, London, UK.

Cruden, R.W.; Hermann, H.M. \& Peterson, S. (1983). Patterns of nectar production and plant-pollinator coevolution. In: The biology of nectaries, B. Bentley \& T. Elias, 80-125, Columbia Univ. Press, New-York.

Decourtye, A.; Odoux, J.F. \& Cluzeau-Moulay, S. (2008). Influence des aménagements floristiques sur les abeilles. Bulletin Technique Apicole, Vol.35, No.3, pp. 114-123.

Decourtye, A. \& Devillers, J. (2010). Ecotoxicology of neonicotinoids insecticides in the bees. In: Insect Nicotinic Acetylcholine Receptors, S. Thany (Ed.), 85-95, Landes Bioscience.

Decourtye, A; Mader, E. \& Desneux, N. (2010). Landscape enhancement of floral resources for honey bees in agro-ecosystems. Apidologie, Vol.41, pp. 264-277.

Degrandi-Hoffman, G.Y.; Chen, E.; Huang, M. \& Huang H. (2010). The effect of diet on protein concentration, hypopharyngeal gland development and virus load in worker honey bees (Apis mellifera L.). Journal of Insect Physiology, Vol.56, pp. 11841191.

de Groot, A.P. (1953). Protein and amino acid requirements of the honey bee (Apis mellifica L.). Physiologia Comparata et Oecologa, Vol.3, pp. 197-285.

Desneux, N.; Decourtye, A. \& Delpuech, J.M. (2007). The sublethal effects of pesticides on beneficial arthropods. Annual Review of Entomology, Vol.52, pp. 81-106.

Dicks, L.V.; Showler, D.A. \& Sutherland, W.J. (2010). Bee conservation: evidence for the effects of interventions. Pelagic Publishing (Ed.), Exeter, UK.

Dimou, M. \& Thrasyvoulou, A. (2009). Pollen analysis of honeybee rectum as a method to record the bee pollen flora of an area. Apidologie, Vol.40, pp. 124-133.

Dyer, F.C. (1996). Spatial memory and navigation by honeybees on the scale of the foraging range. Journal of Experimental Biology, Vol.199, pp. 147-154.

Dyer, A.G., Rosa, M.G. \& Reser, D.H. (2008). Honeybees can recognise images of complex natural scenes for use as potential landmarks. Journal of Experimental Biology, Vol.211, pp. 1180.

Elias T. (1983). Extrafloral nectaries: their structure and distribution. In: The biology of nectaries, B. Bentley \& T. Elias (Eds.), 174-203, Columbia University Press, NewYork, USA.

Feuillet, D.; Odoux, J.F.; Mateescu, C.; Aupinel, P.; Lamy, H.; Moreau, N.; Roucher, L. \& Souché, T. (2008). Evolution floristique et physico-chimique des pollens récoltés au cours de l'année 2006 sur le site de l'INRA du Magneraud. Bulletin Technique Apicole, Vol.35, No.1, pp. 20-26.

Gallai, N.; Salles, J.M.; Settele, J. \& Vaissière, B.E. (2009). Economic valuation of the vulnerability of world agriculture confronted with pollinator decline. Ecological Economics, Vol.68, pp. 810-821.

Genissel, A.; Aupinel, P.; Bressac, C.; Taséi, J-N. \& Chevrier C. (2002). Influence of pollen origin on performance of Bombus terrestris micro colonies. Entomologia Experimentalis et Applicata, Vol.104, pp. 329-336. 
Giersch, T.; Barchia, I. \& Hornitzky M. (2010). Can fatty acids and oxytetracycline protect artificially raised larvae from developing European foulbrood? Apidologie, Vol.41, pp. 151-159.

Gould, J.L. \& Gould, C.G. (1988). The honey bee. Scientific American Library, New-York, USA.

Haydak, M.H. (1970). Honey bee nutrition. Annual Review of Entomology, Vol.15, pp. 143-156.

Heard, M.S.; Carvell, C.; Carreck, N.L.; Rothery, P.; Osborne, J.L. \& Bourke, A.F.G. (2007). Landscape context not patch size determines bumble-bee density on flower mixtures sown for agri-environment schemes. Biology Letters, Vol.3, pp. 638-641.

Henry, M.; Fröchen, M.; Maillet-Mezeray, J.; Breyne, E.; Allier, F.; Odoux, J.-F. \& Decourtye, A. (2012). Spatial autocorrelation in honeybee foraging activity reveals optimal focus scale for predicting agro-environmental scheme efficiency. Ecological modelling, in press.

Jablonski, B. (2001). Agronomic and beekeeping value of short-tube populations of red clover (Trifolium pratense L.). Journal of Apicultural Science, Vol.45, pp. 37-50.

Jamieson, C.A. \& Austin, G.M. (1956). Preferences of honeybees for sugar solutions, Proceedings of International Congress of Entomology, pp. 1059-1062, Montréal, Québec, 1956.

Jay, S.C. \& Jay D.H. (1993). The effect of kiwifruit (Actinidia deliciosa A. Chev.) and yellow flowered broom (Cytisus scoparius Link) pollen on the ovary development of worker honey bees (Apis mellifera L). Apidologie, Vol.24, pp. 557-563.

Johnson, R.M.; Evans, J.D.; Robinson, G.E. \& Berenbaum, M.R. (2009). Changes in transcript abundance relating to colony collapse disorder in honey bees (Apis mellifera). Proceedings of the National Academy of Sciences USA, Vol.106, pp. 14790-14795.

Johnson R.M., Ellis M.D., Mullin C.A., Frazier M. (2010) Pesticides and honey bee toxicity USA, Apidologie vol.41, pp 312-331.

Kevan, P. (1977). Blueberry crops in Nova Scotia and New Brunswick - pesticides and crop reductions. Canadian Journal of Agricultural Economics, Vol.25, pp. 61-64.

Kleijn, D.; Baquero, R.A.; Clough, Y.; Díaz, M.; Esteban, J.; Fernández, F.; Gabriel, D.; Herzog, F.; Holzschuh, A.; Jöhl, R.; Knop, E.; Kruess, A.; Marshall, E.J.P.; SteffanDewenter, I.; Tscharntke, T.; Verhulst, J.; West, T.M. \& Yela, J.L. (2006). Mixed biodiversity benefits of agri-environment schemes in five European countries. Ecology Letters, Vol.9, pp. 243-254.

Kleijn, D.; Kohler, F.; Báldi, A.; Batáry, P.; Concepción, E.D; Clough, Y.; Díaz, M.; Gabriel, D.; Holzschuh, A.; Knop, E.; Kovács, A.; Marshall, E.J.P.; Tscharntke, T. \& Verhulst, J. (2009). On the relationship between farmland biodiversity and land-use intensity in Europe. Proceedings of the Royal Society B: Biological Sciences, Vol.276, pp. 903-909.

Klein, A. M., B. E. Vaissière, J. H. Cane, I. Steffan-Dewenter, S. A. Cunningham, C. Kremen, et T. Tscharntke. 2007. Importance of pollinators in changing landscapes for world crops. Proceedings of the Royal Society B 274:303-313.

Kohler, F.; Verhulst, J.; van Klink, R. \& Kleijn, D. (2008). At what spatial scale do high-quality habitats enhance the diversity of forbs and pollinators in intensively farmed landscapes? Journal of Applied Ecology, Vol.45, pp. 753-762.

Leblanc, B.W.; Davis, O.K.; Boue, S.; DeLucca, A. \& Deeby, T. (2009). Antioxidant activity of Sonoran Desert bee pollen. Food Chemistry, Vol.115, pp. 1299-1305. 
Le Conte, Y.; Ellis, M. \& Ritter, W. (2010). Varroa mites and honey bee health: can Varroa explain part of the colony losses? Apidologie, Vol.41, pp. 353-363.

Loper, G.M. \& Waller, G.D. (1970). Alfalfa flower aroma and flower selection by honey bees. Crop Science, vol.10, pp. 66-68

Loper, G.M. \& Cohen A.C. (1987). Amino-acid content of dandelion pollen, a honey bee (Hymenoptera, Apidae) nutritional evaluation. Journal of Economic Entomology, Vol.80, pp. 14-17.

Louveaux, J. (1959). Recherches sur la récolte du pollen par les abeilles (Apis mellifera L.). Annales de l'abeille, Vol.2, pp. 99.

Manning, R. (2001). Fatty acids in pollen: a review of their importance for honey bees. Bee World, Vol.82, pp. 60-75.

Mattila, H.R. \& Otis, G.W. (2006). Influence of pollen diet in spring on development of honey bee (Hymenoptera: Apidae) colonies. Journal of Economic Entomology, Vol.99, pp. 604-613.

Maurizio, A. (1950). The influence of pollen feeding and brood rearing on the length of life and physiological condition of the honeybee. Bee World, Vol.31, pp. 9-12.

Maurizio, A. (1954). Pollen: its composition, collection, utilization, and identification. Bee World, Vol.35, pp. 49-50.

Maurizio, A. (1975). How bees make honey. In: Honey, a comprehensive survey, E. Crane (Ed), 77-105, Heinemann, London, UK.

Menzel, R.; Greggers, U. \& Hammer, M. (1993). Functional organization of appetitive learning and memory in a generalist pollinator, the honey bee. In: Insect learning, D.R. Papaj \& A.C. Lewis, 79-125, Chapman Hall, New-York, USA.

Mesquita, L.X.; Maracajà, P.B.; Sakamoto, S.M. \& Soto-Blanco, B. (2010). Toxic evaluation in honey bees (Apis mellifera) of pollen from selected plants from the semi-arid region of Brazil. Journal of Apicultural Research, Vol.49, pp. 265-269.

Morais, M.; Moreira, L.; Feas, X. \& Estevinho, L.M. (2011). Honeybee-collected pollen from five Portuguese Natural Parks: Palynological origin, phenolic content, antioxidant properties and antimicrobial activity. Food Chemistry and Toxicology, Vol.49, pp. 1096-1101.

Naug D. (2009). Nutritional stress due to habitat loss may explain recent honeybee colony collapses. Biological Conservation, Vol.142, pp. 2369-2372.

Neumann, P. \& Carreck, N.L. (2010). Honey bee colony losses. Journal of Apicultural Research, Vol.49, No.1, pp. 1-6.

Odoux, J.F.; Lamy, H. \& Aupinel, P. (2004). L'abeille récolte-t-elle du pollen de maïs et de tournesol? La Santé de l'Abeille, Vol.201, pp. 187-193.

Odoux, J.F.; Caro, G.; Touillet, C.; Peyra, E.; Derelle, D.; Aupinel, P. \& Bretagnolle, V. (2009). Which landscape features influence population ecology of bee colonies in farmland intensive cereals systems? Proceedings of Apimondia 41th Congress, Montpellier, France, September 15-20, 2009.

Odoux, J.F.; Feuillet, D.; Aupinel, P.; Loublier, Y.; Taséi, J.N. \& Mateescu C. (2010). Territorial biodiversity in cropping system and consequences on physico-chemical characteristics of collected pollen. Proceedings of Eurbee $4^{\text {th }}$ European Conference of Apidology, Ankara, Turkey, September 7-9, 2010.

Oldroyd, B.P. (2007). What's killing American honey bees? PLoS Biology, Vol.5, pp. 11951199. 
Ollerton, J.; Winfree, R. \& Tarrant, S. (2011). How many flowering plants are pollinated by animals? Oikos, Vol.120, pp. 321-326.

Pain, J. \& Maugenet, J. (1966). Recherches biochimiques et physiologiques sur le pollen emmagasiné par les abeilles. Annales de l'abeille, Vol.9, pp. 209-236.

Page, R.E.; Waddington, K.D.; Hunt, G.J. \& Fondrk, M.K. (1995). Genetic determinants of honey bee foraging behaviour. Animal Behaviour, Vol.50, pp. 1617-1625.

Pernal S.F. and Currie R.W. (2000) Pollen quality of fresh and 1-year-old single pollen diets for worker honey bees (Apis mellifera L.). Apidologie vol.31, pp 387-409.

Pierre, J.; Mesquida, J.; Marilleau, R.; Pham-Delègue, M.H. \& Renard, M. (1999). Nectar secretion in winter oilseed rape, Brassica napus - quantitative and qualitative variability among 71 genotypes. Plant Breeding, Vol.118, pp. 471-476.

Pierre, J. \& Renard, M. (1999). Plant development mutants : incidence on honey bees behaviour and pollination. Proceedings of 10th International Rapeseed Congress, pp. 2629 Canberra, Australia, September 26-29, 1999.

Rader, R.; Howlett, B.G.; Cunningham, S.A.; Westcott, D.A.; Newstrom-Lloyd, L.E.; Walker, M.K.; Teulon, D.A.J. \& Edwards W. (2009). Alternative pollinator taxa are equally efficient but not as effective as the honeybee in a mass flowering crop. Journal of Applied Ecology, Vol.46, pp. 1080-1087.

Ribbands, C.R. (1953). The behaviour and social life of honeybees. London Bee Research Association, London, UK.

Robinson, W.S. (1981). Honey bees Apis mellifera development of foraging fidelity to Delicious apple flowers. Journal of Economic Entomology, Vol.74, pp. 127-130.

Roulston, T.H. \& Buchmann, S.L. (2000). A phylogenetic reconsideration of the pollen starch-pollination correlation. Evolutionary Ecology Research, Vol.2, pp. 627-643.

Roulston, T.H. \& Cane, J.H. (2000). Pollen nutritional content and digestibility for animals. Plant Systematics and Evolution, Vol.222, pp. 187-209.

Schmickl, T. \& Crailsheim, K. (2001). Survival of honeybee larvae in times of pollen stress. Apidologie, Vol.32, pp. 496-498.

Schmidt, J.O. (1984). Feeding preferences of Apis mellifera L. (Hymenoptera: Apidae): individual versus mixed pollen species. Journal of the Kansas Entomological Society, Vol.57, pp. 323-327.

Schmidt, J.O.; Thoenes, S.C. \& Levin, M.D. (1987). Survival of honey bees, Apis mellifera (Hymenoptera: Apidae), fed various pollen sources. Journal of Economic Entomology, Vol.80, pp. 176-183.

Schmidt, L.S.; Schmidt, J.O.; Rao, H.; Wang, W. \& Xu, L. (1995). Feeding preference and survival of young worker honey bees (Hymenoptera:Apidae) fed rape, sesame, and sunflower pollen. Journal of Economic Entomology, Vol.88, pp. 1591-1595.

Seeley, T. (1985). Honeybee ecology: a study of adaptation in social life. Princeton University Press, Princeton, UK.

Severson, D.W. \& Parry, J.E. (1981). A chronology of pollen collection by honey bees. Journal of Apicultural Research, Vol.20, pp. 97-103.

Sigurdson, J.E. (1981a). Automated discrete trials techniques of appetitive conditioning in honeybees. Behaviour Research Methods and Instruments, Vol.13, pp. 1-10.

Sigurdson, J.E. (1981b). Measurement of consummatory behaviour of honeybees. Behaviour Research Methods and Instruments, Vol.13, pp. 308-310. 
Singh, S. (1950). Behavior studies of honeybees in gathering nectar and pollen. Annual Report of Cornell University Agricultural Experimental Station, Vol.288, 57 pp.

Singh, S.; Saini, K. \& Jain, K.L. (1999). Quantitative comparison of lipids in some pollens and their phagostimulatory effects in honey bees. Journal of Apicultural Research, Vol.38, pp. 87-92.

Stanley, R.G. \& Linskens, H.F. (1974). Pollen: Biology, biochemistry, management. Springer Heidelberg, Germany.

Steffan-Dewenter, I.; Münzenberg, U.; Bürger, C.; Thies, C. \& Tscharntke, T. (2002). Scaledependent effects of landscape context on three pollinator guilds. Ecology, Vol.83, pp. 1421-1432.

Steffan-Dewenter, I. \& Kuhn, A. (2003). Honeybee foraging in differentially structured landscapes. Proceedings of the Royal Society of London Series B-Biological Sciences, Vol.270, pp. 569-575.

Taséi, J.N. \& Aupinel, P. (2008). Nutritive value of 15 single pollens and pollen mixes tested on larvae produced by bumblebee workers (Bombus terrestris, Hymenoptera: Apidae). Apidologie, Vol.39, pp. 397-409.

Taylor, P.D.; Fahrig, L.; Henein, K. \& Merriam, G. (1993). Connectivity is a vital element of landscape structure. Oikos, Vol.68, pp. 571-573.

Thorp, R.W.; Briggs, D.L.Jr.; Estes, R. \& Erickson, E.H. (1975). Nectar fluorescence under ultraviolet irradiation. Science, Vol.189, pp. 476-478.

Townsend, P.A. \& Levey, D.J. (2005). An experimental test of whether habitat corridors affect pollen transfer. Ecology, Vol.86, pp. 466-475.

Vaissière, B.E. \&Vinson, S.B. (1994). Pollen morphology and its effect on pollen collection by Honey-bees, Apis mellifera (Hymenoptera, Apidae), with special reference to upland cotton, Gossypium-Hirsutum L. (Malvaceae). Grana, Vol.33, pp. 128-138.

van Buskirk, J. \& Willi, Y. (2004). Enhancement of farmland biodiversity within set-aside land. Conservation Biology, Vol.18, pp. 987-994.

Vaissière, B.E.; Rodet, G.; Cousin, M.; Botella, L. \& Torre Grossa, J.P. (1996). Pollination effectiveness of honey bees in a kiwifruit orchard. Journal of Economic Entomology, Vol.89, pp. 453-461.

vanEngelsdorp, D.; Underwood, R.; Caron, D. \& Hayes, J. Jr. (2007). An estimate of managed colony losses in the winter of 2006-2007: a report commissioned by the Apiary Inspectors of America. American Bee Journal, Vol.147, pp. 599-603

vanEngelsdorp, D.; Evans, J.D.; Saegerman, C.; Mullin, C.; Haubruge, E.; Nguyen, B.K.; Frazier, M.; Frazier, J.; Cox-Foster, D.; Chen, Y.; Underwood, R.; Tarpy, D.R. \& Pettis, J.S. (2009). Colony Collapse Disorder: A Descriptive Study. PLoS ONE, Vol.4, No.8.

vanEngelsdorp, D.; Hayes J. Jr.2; Underwood, R.M.; Caron, D. \& Pettis J. (2011). A survey of managed honey bee colony losses in the USA, fall 2009 to winter 2010. Journal of Apicultural Research, Vol.50, No.1, pp. 1-10.

van Geert, A.; van Rossum, F. \& Triest, L. (2010). Do linear landscape elements in farmland act as biological corridors for pollen dispersal? Journal of Ecology, Vol.98, pp. 178187.

von Frisch, K. (1967). The dance language and orientation of bees. Cambridge, UK.

Waddington, K.D. \& Kirchner, W.H. (1992). Acoustical and behavioral correlates of profitability of food sources in honey bee round dances. Ethology, Vol.92, pp. 1-6. 
Wahl, O. \& Ulm, K. (1983). Influence of pollen feeding and physiological condition on pesticide sensitivity of the honey bee Apis mellifera carnica. Oecologia, Vol.59, pp. 106-128.

Waller G.D. (1972). Evaluating responses of honeybees to sugar solutions using an artificial feeder. Annals of Entomological Society of America, Vol.65, pp. 857-861.

Wille, H.; Imdorf, A.; Buhlmann, G.; Kilchenmann, V. \& Wille, M. (1985). Beziehung zwischen Polleneintrag Brutaufzucht und mittlerer Lebenserwartung der Arbeiterinnen in Bienenvölkern (Apis mellifica L.). Bulletin de la Société Entomologique Suisse, Vol.58, pp. 205-214.

Winston, M.L. (1987). The Biology of the Honey Bee. Harvard University Press, Cambridge, UK. 


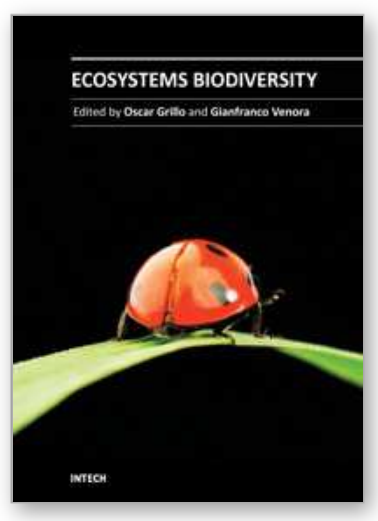

\author{
Ecosystems Biodiversity \\ Edited by PhD. Oscar Grillo
}

ISBN 978-953-307-417-7

Hard cover, 464 pages

Publisher InTech

Published online 16, December, 2011

Published in print edition December, 2011

Ecosystems can be considered as dynamic and interactive clusters made up of plants, animals and microorganism communities. Inevitably, mankind is an integral part of each ecosystem and as such enjoys all its provided benefits. Driven by the increasing necessity to preserve the ecosystem productivity, several ecological studies have been conducted in the last few years, highlighting the current state in which our planet is, and focusing on future perspectives. This book contains comprehensive overviews and original studies focused on hazard analysis and evaluation of ecological variables affecting species diversity, richness and distribution, in order to identify the best management strategies to face and solve the conservation problems.

\title{
How to reference
}

In order to correctly reference this scholarly work, feel free to copy and paste the following:

Decourtye Axel, Alaux Cédric, Odoux Jean-François, Henry Mickaël, Vaissière Bernard E. and Le Conte Yves (2011). Why Enhancement of Floral Resources in Agro-Ecosystems Benefit Honeybees and Beekeepers?, Ecosystems Biodiversity, PhD. Oscar Grillo (Ed.), ISBN: 978-953-307-417-7, InTech, Available from: http://www.intechopen.com/books/ecosystems-biodiversity/why-enhancement-of-floral-resources-in-agroecosystems-benefit-honeybees-and-beekeepers-

\section{INTECH}

open science | open minds

\section{InTech Europe}

University Campus STeP Ri

Slavka Krautzeka 83/A

51000 Rijeka, Croatia

Phone: +385 (51) 770447

Fax: +385 (51) 686166

www.intechopen.com

\section{InTech China}

Unit 405, Office Block, Hotel Equatorial Shanghai

No.65, Yan An Road (West), Shanghai, 200040, China

中国上海市延安西路65号上海国际贵都大饭店办公楼 405 单元

Phone: +86-21-62489820

Fax: +86-21-62489821 
(C) 2011 The Author(s). Licensee IntechOpen. This is an open access article distributed under the terms of the Creative Commons Attribution 3.0 License, which permits unrestricted use, distribution, and reproduction in any medium, provided the original work is properly cited. 